\title{
Construction of Teaching Quality Assurance System in Project Driven and Centralized Teaching
}

\author{
Jianqiang Wang \\ School of information engineering, Yulin University, Yulin, Shaanxi, China \\ 317950860@qq.com
}

\begin{abstract}
Keywords: Teaching quality assurance; Internet of things; Talent cultivation orientation; Teaching reform; Project driven
\end{abstract}

\begin{abstract}
The monitoring of teaching quality is a problem that has been explored in Colleges and universities. High school is the product of talent, is all kinds of talents needed for economic development and social stability, and the quality of talents, and the cultivation of University depends on four years of undergraduate education, undergraduate teaching centered teaching must solve the teaching quality guarantee system construction problems. Several aspects of the talent cultivation orientation, from project selection, teacher training, textbook construction and teaching process management, discusses the project driven and the construction of teaching quality assurance system in the way of centralized instruction teaching.
\end{abstract}

\section{Introduction}

Project driven and focused on teaching methods to explore, to prepare students to solve the "project" to grasp the overall problem, as an attempt of teaching reform, the curriculum construction ideas generally includes three parts: project driven, engineering angle module teaching content, teaching modules[1-3].The implementation measures are as follows: selecting an actual networking project, the "first, then, finally, the total", from the engineering point of view, the module can be divided into 7 or so (the individual module by the enterprise engineers and teachers to complete teaching); each module of centralized teaching, arrange 48 hours two, a week after the completion of the teaching, teaching immediately arrange course examination; develop the final arrangements for two weeks for the project, guiding students to organize their own team to complete a work and the project project is developed, the last week of defense project arrangement[4-6]..

The Ministry of Education issued "several opinions on" strengthening undergraduate education to improve teaching quality of schools at all levels should notice requirements of the actual situation, according to the requirements of talents training in the new century, the continuous deepening of the reform of teaching management system, optimize the teaching process control; the establishment of employers, teachers and students to participate in teaching quality internal evaluation and authentication mechanism[7-9]; establish and improve the teaching quality monitoring and assurance system. As a new teaching method reform, it is particularly important to construct the guarantee system of teaching quality, several aspects from the talent cultivation orientation, project selection, teacher training, textbook construction and teaching process management, discusses the project driven and the construction of teaching quality assurance system in the way of teaching focus on teaching[10].

\section{Construction of Teaching Quality Guarantee System}

Personnel Training Orientation. In order to better realize the training of applied talents, we should grasp the orientation of personnel training in the whole talent training program, and constantly revise the personnel training programs. On the one hand, starting from the market demand, the employment market for research, on the other hand, in-depth business, and in-depth communication with front-line engineers to grasp the current job market demand for talent specifications.

Training for Teachers. According to the project requirements, and intends to send in August 2017 no less than 4 people out of training related content; According to the needs of the project, we 
intend to invite the enterprise engineers to complete the teaching work of individual modules with the teachers of our college.

Project selection. In the modular teaching of the sense of control and the control of the Internet of things, we select a few examples of the actual project of Internet of things, such as smart home system, intelligent agricultural system, telemedicine, etc.. These examples are different levels of the three levels of the Internet of things (perception layer, transport layer, application layer) application. Therefore, we choose such a project in teaching. The use of teachers to do their own hardware system integration, the way to complete their own software system or networking with something to develop a set of practical teaching management system for our hospital. Taking this kind of project as a practical project in Teaching.

Design of Teaching Content. In the selection of teaching content, we should follow the "use what" what principle, according to the division of the project capacity module, give the students to explain the relevant knowledge points, the rest of the content temporarily make less or do not speak, pending rectification after the completion of the project implementation, according to the schedule, the rest of the content selected readings.

In the selection of teaching materials, the characteristics of engineering professional networking, and based on project driven teaching reform is a new attempt to the professional direction, so the suitable textbook basically no training materials, we use textbooks or choose domestic stage better some school outside this way, teaching materials the content can be suitable for our teaching practice.

Teaching Methods and Procedures. Take the way of centralized teaching of each sub module:

(1) A fixed laboratory is required to be completed in the laboratory.

(2)The students bring their own notebook, the requirements of the laboratory access to wireless WiFi network power supply and other basic conditions.

(3) The teacher teaches, the students operate.

\section{Teaching Process Quality Assurance}

(1)The teacher assigned the task of the day, in the second days before the completion of the examination, and according to the results of processing;

(2) Students complete homework, experiment and study log every day;

(3)Each sub module for each student to build a normal test table, including the daily performance of the class, the completion of the work and the completion of the learning log;

(4)All the students every day to complete the task of data into a word document, name for module + day; all data of a single module students into a document, named after the two number + name + module name for inspection.

(5)Explore the reform and optimization of examination methods, to be used in peacetime results $(50 \%)+$ final written examination results $(50 \%)$.

\section{Summary}

In the teaching process, according to the work plan and the requirements of teaching, teaching management, adhere to a few weeks of teaching meeting, chaired by the president in charge of teaching. According to the teaching schedule in the teaching week time in the early, middle and later by monitoring a corresponding checklist, such as pre planned schedule, topic approval form; the middle mid-term examination table, student evaluation form; late course summary table, excellent design (Thesis) award application form etc.. This form of inspection by the teachers involved in teaching activities, students, teaching the leadership of the specific fill, played a good role in supervision and self supervision.

Higher education system is a dynamic system, is a complex system engineering, to ensure the system target system and the monitoring system is to improve the quality of teaching, is a problem in two aspects, is the pre inspection and adjustment of guarantee system of teaching quality and general factors, there are different requirements in different the period, so only the system structure and content factors should be adjusted in a timely manner to enrich, pay special attention to the two aspects of the work, in order to improve the teaching quality of teaching. 


\section{Acknowledgements}

This paper is a report of the research project of teaching reform in the Information Engineering Institute of Yulin University.

\section{References}

[1] Shao Yijiang, Liu Hong. Construction of modular teaching system based on ability oriented theory and practice of modular teaching reform in Hefei University [J]. Journal of Hefei University (NATURAL SCIENCE EDITION), 2013,(04):58-63. (in Chinese)

[2] Min Yuan, Xu Qiang, Wang Xiaofeng, et al. Study on Modular Teaching Reform of applied talents from Germany FH J. Based on the successful experience of Journal of Hefei University (NATURAL SCIENCE EDITION), 2011, 21 (4): 56 - 65 (in Chinese)

[3] Lin Yuan Xiang. Application of project driven method in computer network experiment teaching [J]. Experimental science and technology, 2011, 9(4) : 112-116. (in Chinese)

[4] Peng Yuanfang, Lu Qin, Hu Ning, et al. Exploration and practice of integrated teaching of single chip microcomputer based on project driven method [J]. Computer education, 2010 (6): 82. (in Chinese)

[5] Cai Jingmin, Chen Xiao. The modular construction of ability oriented teaching system -- Taking Hefei University as an example [M] . Hefei University of Science \& Technology China press, 2012: 9 (in Chinese)

[6] Cao Zhonghong, Wei Zhu Bao. Reconstruction of competency based training system for Applied Talents: an exploration into the reform of Accounting Specialty in Hefei University [J]. Journal of Hefei University (NATURAL SCIENCE EDITION), 2011,(04):61-65. (in Chinese)

[7] Xu Zeyin, Xu Qiang, Zheng Zheng Meng. Mechanical design manufacturing and automation professional modular teaching reform and practice of $[\mathrm{J}]$. Journal of Hefei University (NATURAL SCIENCE EDITION), 2015, (02): 78-81. (in Chinese)

[8] Liu Haijun, taking iron. PLC course reform of modular teaching practice [J]. Journal of Yulin University, 2015, (02): 70-72. (in Chinese)

[9] Li Ming. Modular inorganic chemistry teaching reform in local universities to explore [J]. Journal of Qinzhou University, 2015, (11): 24-28. (in Chinese)

[10]Chen Tong. Bao Shudi, Public computer module teaching reform based on MOOC [J]. Journal of Ningbo University of Technology, 2014, (04): 86-91. (in Chinese) 